\title{
EFFICIENCY OF WHITE LUPIN GRAIN IN COMPOSITION OF FEED FOR DAIRY CATTLE
}

\author{
Nikolay Buryakov, Maria Buryakova, Evgeniy Prokhorov, Dmitriy Aleshin \\ Russian Timiryazev State Agrarian University, Russia \\ kormlenieskota@gmail.com,m.buryakova@gmail.com,dgek1589@gmail.com, \\ pitanieskota@gmail.com
}

\begin{abstract}
Experimental data are presented on the use of feed concentrates containing different levels of white grain of the RSAU-MTAA breeding (grade Degas) in feeding of highly productive lactating cows. In the process of physiological experiences were studied: amino acid composition of grain, milk production, nitrogen balance and digestibility of nutrients of lactating cow diets. The article presents results of the study of milk productivity and nitrogen balance with the use of white lupine grain in the composition of feed for highly productive cows in the amount of $18 \%, 24 \%$ and $30 \%$ of the total nutritional content of the concentrate portion of the diet. Lupin was introduced instead of other expensive traditional protein feeds: rapeseed cake, sunflower meal with crude fiber and crude protein content of $19 \%$ and $34 \%$, respectively, while maintaining the overall energy and protein nutritional value of the feed. It was found that the content of essential amino acids in lupine grain was higher by $4.34 \%$ compared to other varieties of white lupine grown in Russia, and it is not inferior to other more common high-protein feed (soybean, soybean meal, sunflower meal, etc.). The inclusion of $24 \%$ of white lupine grain in the feed resulted in significant increase in the average daily milk yield of natural fat content by $6.0 \%$ and protein content in milk by $7.07 \%$ compared to the control group. The introduction of white lupine concentrate into the compound feed did not have a negative impact on milk productivity and nitrogen balance. All animals had a positive nitrogen balance. The greatest nitrogen of the diet was absorbed by cows receiving $24 \%$ of the grain of white lupine in feed, both from accepted and digested and amounted to $30.5 \%$ and $41.5 \%$, respectively.
\end{abstract}

Key words: milk productivity, lupine, compound feed, feeding, digestibility, amino acids, cattle.

\section{Introduction}

The high realization of the genetic potential of dairy productivity of cattle fully appears by the full balanced feeding, with a significant impact on the health, growth, milk productivity and high economic efficiency of production [1-4].

For optimization of rumen digestion in dairy cow diets carbohydrates rich in energy, essential bacterial flora for use of ammonia and microbial protein synthesis should be easily digestible and nonstructural. The optimal environment of the rumen content is by constant $\mathrm{pH}$ of the medium within 6.5-6.8 and can vary both in acidic and alkaline side; it depends on the following factors: the type and quality of food, the method of preparing it for feeding, the structure of the diet, etc. The decrease in the concentration of rumen liquid content $\mathrm{pH}$ is from 4.0 to 5.0 or increased to 7.5 leads to the disruption of the digestive process, reducing the consumption and digestibility of feed means and perhaps may cause the ruminal tympany of cows $[1 ; 2 ; 4-6]$. The energy requirements of dairy cows can be replenished by oxidation of carbohydrates, fats and proteins, and the need for essential amino acids - only by entering the diet of feed $[2 ; 3 ; 7 ; 8]$.

It is known that the need for essential amino acids of highly productive dairy cows is satisfied by the synthesis of microbial protein and amino acids in the rumen and by entry of a full-fledged by-pass protein into the bowel $[3 ; 4 ; 8 ; 9]$.

The digestibility of crude protein is affected by the content of protein and non-protein nitrogen in feed, the content of easily soluble fraction, resulting in splitting of protein feed within 40-80\% $[1 ; 2 ; 4 ; 6 ; 7]$.

Under the influence of bacteria and protozoa of the rumen are degradable: rhamnolipids and bioses $-85-95 \%$, starch $-75 \%$, crude fiber $-70 \%$, crude protein - from $40 \%$ to $60 \%$. In this case, the digestibility of protein in the gastrointestinal tract depends on the composition of amino acids, structural connection, ratio of its fractions in the protein, dispersion and so on $[4 ; 6 ; 8 ; 10]$.

Digestibility of feed raw protein affects the satisfaction of highly productive dairy cattle in amino acids, proteins, with high digestibility in the bowel come to $50 \%$, at low $-50-65 \%$ of amino acids in the form of unsolvable fraction $[2 ; 4]$. 


\section{Materials and methods}

The study was conducted on the farm of FSUE "Poyma" of the Russian Agricultural Academy of Lukhovitsky district of Moscow region. For this purpose, deep-seated cows of Holstein breed 2-3 lactation, which were at 9 months of pregnancy with a live weight of $612 \mathrm{~kg}$ and the milk yield for the previous lactation 8-9 thousand $\mathrm{kg}$ and distributed to 4 experimental groups of 7 heads each, were selected by the method of pairs-analogues. The experimental animals were in the same conditions of maintenance and feeding during the experiment and were clinically healthy. Cows were in conditions of the tie-up housing system.

Control group of animals received concentrated mixed cattle feed, which was balanced nutritionally, meets the requirements of feeding of the Russian Academy of Agricultural Sciences (2003) and counted to receive the average daily milk yield of $40 \mathrm{~kg}$ of milk subject to the milk yield.

The diets of the experimental groups of cows included feed concentrate containing different levels of white lupine grains $(18,24$ and $30 \%$ ) with a decrease in the level of rapeseed cake and soybean meal. The feed content of the exchange energy and the level of crude protein corresponded to the feed of the control group.

The feed of different levels of lupine grain was introduced into the compound feed in accordance with the GOST 9268-2015 "Compound feed-concentrates for cattle. Technical conditions" by replacing other protein feeds with maintaining energy and protein nutrition.

The composition of feed concentrates with inclusion in their composition white Degas lupine seeds for highly productive Holstein cows is shown in Table 1.

Table 1

Composition of compound feeds-concentrates for cows, $\%$

\begin{tabular}{|c|c|c|c|c|c|}
\hline \multirow[b]{2}{*}{ Component } & \multirow{2}{*}{$\begin{array}{c}\text { Maximum level } \\
\text { of the } \\
\text { component } \\
\text { input }\end{array}$} & \multicolumn{4}{|c|}{ Group of animals } \\
\hline & & Control & $1^{1^{\text {st }}}$ & $\begin{array}{c}2^{\text {nd }} \\
\text { experimental }\end{array}$ & $\begin{array}{c}3^{\text {rd }} \\
\text { experimental }\end{array}$ \\
\hline Maize & 50.0 & 37.0 & 28.8 & 28.0 & 17.0 \\
\hline Barley & 70.0 & 25.0 & 25.6 & 34.0 & 44.0 \\
\hline White lupine & 10.0 & - & 18.0 & 24.0 & 30.0 \\
\hline $\begin{array}{c}\text { Sunflower meal, } \\
\text { CP }-34 \% \\
\text { CF }-19 \%\end{array}$ & 25.0 & 20.0 & 3.2 & 6.0 & - \\
\hline Rapeseed cake & 10.0 & 11.2 & 6.9 & - & - \\
\hline Wheat bran & 40.0 & 5.0 & 14.0 & 4.0 & 5.0 \\
\hline Table salt & 1.2 & 0.6 & 1.0 & 1.2 & 1.2 \\
\hline Premix P60-4 No. 1 & 3.0 & 1.0 & 1.0 & 1.2 & 1.2 \\
\hline $\begin{array}{c}\text { Monocalcium } \\
\text { phosphate }\end{array}$ & 2.0 & 0.2 & 1.5 & 1.6 & 1.6 \\
\hline
\end{tabular}

The content of alkaloids in the grain of Degas white lupine was determined in the testing laboratory of the RAMS Institute of Nutrition Center, and the gross content of amino acids in the laboratory of the "Evonik Chimiya" LLC.

Milk productivity and quality during the experiment were measured 3 times a month by the method of control milking. Protein and fat contain in milk were determined in accordance with GOST 25179-90 and GOST 5867-90.

During the balance experiment records were kept on feed and feed residues, urine, feces and milk. Based on their data obtained after chemical analysis of feed, milk, urine and feces, the average daily nitrogen balance was calculated.

Milk sampling for physical and chemical studies was carried out in accordance with the requirements of GOST 26809.1-2014. The study of the qualitative composition of milk was carried out in individual samples monthly during lactation. 
The content of fat $(\%)$ and content protein $(\%)$ were determined in the daily milk sample. The reliability of the results was analyzed with the use of conventional methods of variation statistics by the MS Office Excel computer program.

\section{Results and discussion}

Dairy cows during the process of milk synthesis cannot meet their needs for amino acids due to the synthesis of microbial protein in the rumen. As a result, there was a need for optimization of feeding rations using feed with a high proportion of essential amino acids to meet the deficit $[5 ; 7 ; 8]$. More than $70 \%$ of the amino acids received in the cow's body are required for formation of milk. Under the studies conducted on lactating cows with an annual milk production of 6-8 thousand $\mathrm{kg}$ with a milk fat content of $3.4 \%$ and a balanced composition of the exchange protein, the need for essential amino acids such as methionine and leucine seemed to be scarce. On average, the following amino acids are used to maintain life: lysine $-36.9 \mathrm{~g} \cdot \mathrm{day}^{-1}$, methionine -6.9 , phenylalanine -10.7 , and leucine $-24.7 \mathrm{~g} \cdot$ day $^{-1}[11]$.

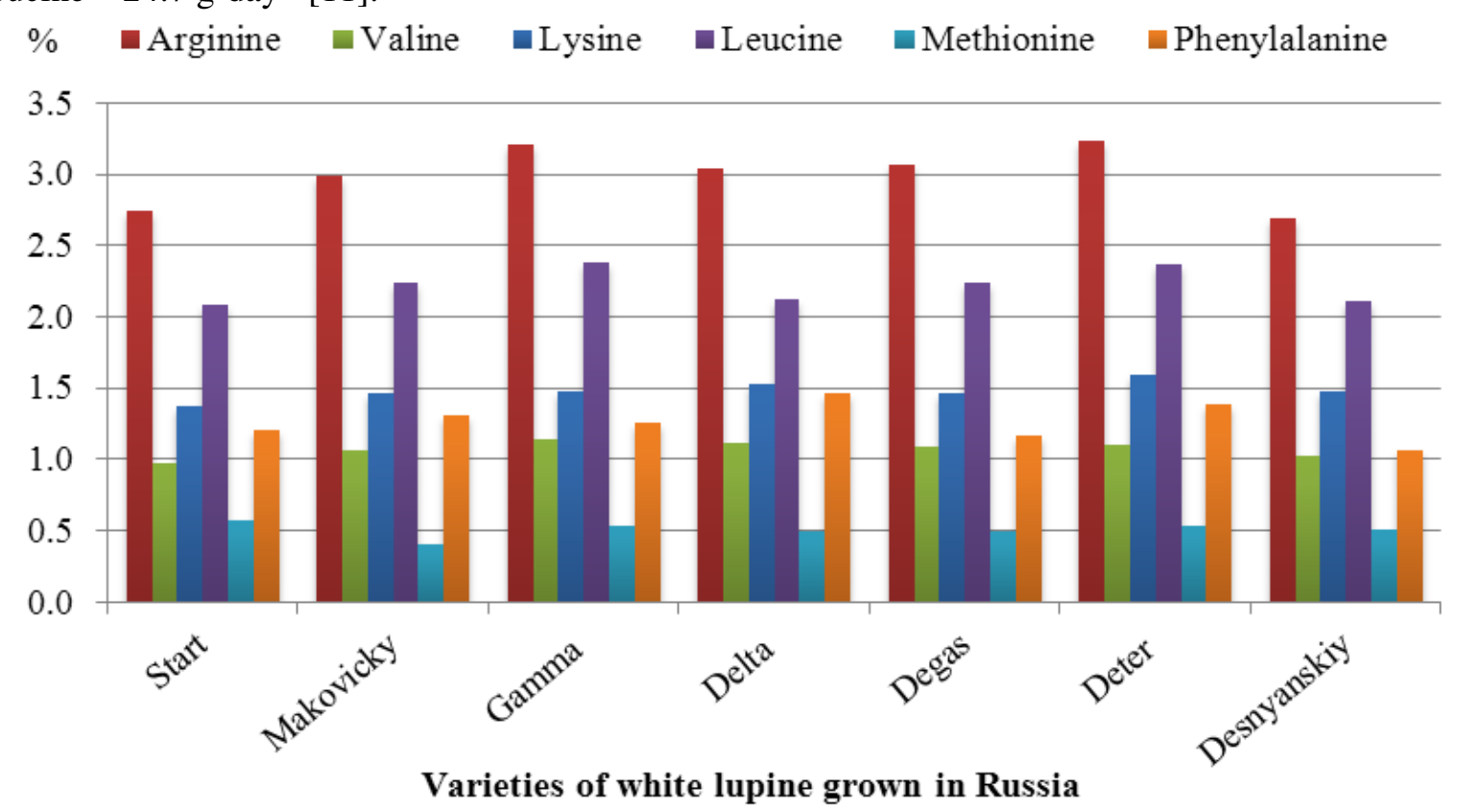

Fig. 1. Amino acid content of white lupine grain, $\%$ of crude protein

Analysis of amino acid and chemical composition of grains of different varieties of white lupine showed that the grade Gamma crude protein content was higher by $4.8 \%$ compared to the grade Degas.

The content of essential amino acids in the grain of lysine varieties Degas and Manovitsky slightly inferior the grade Delta, the content of cystine and methionine in the varieties Delta and Degas were at the same level ( $0.5 \%$ of crude protein).

The highest level of arginine was observed in the Deter variety (3.23\% of crude protein), and the lowest in the Desnyansky and Start varieties, which amounted to $2.69 \%$ and $2.75 \%$, respectively. The lysine level was the highest in the Delta variety $(1.53 \%)$, and in the Desnyansky, Gamma and Degas varieties it was at the same level $-1.47-1.48 \%$ of crude protein (Fig. 1).

Milk productivity during the experiment was determined during the whole lactation from the moment of calving. We took into account such indicators of productivity as the average daily milk yield and gross milk yield of natural and $4 \%$ fat, the mass fraction of milk protein and fat as well as milk protein and fat yield. The data on the level of milk production and the chemical composition of milk are given in Table 2. The data shows that the daily milk yield of natural fat in cows of the experimental group 3 was higher in relation to the control group.

The inclusion of white lupine grain in the compound feed helped increase the daily milk yield of natural and $4 \%$ fat content. Milk yield of natural fat content was higher than the control in all experimental groups, and the difference in relation to the control was $4.03 \%, 5.86,2.93 \%$. However, 
it should be noted that with the introduction of feed maximum share of lupine yield relative to other groups increased slightly and amounted to $2.93 \%, 4.03$ and $5.86 \%$, respectively.

Table 2

Milk production and chemical composition of cow milk per lactation $(M \pm m)$

\begin{tabular}{|c|c|c|c|c|}
\hline \multirow{2}{*}{ Indicator } & \multicolumn{4}{|c|}{ Group of animals $(\boldsymbol{n}=7)$} \\
\cline { 2 - 5 } & Control & $\begin{array}{c}\mathbf{1}^{\text {st }} \\
\text { experimental }\end{array}$ & $\begin{array}{c}\mathbf{2}^{\text {nd }} \\
\text { experimental }\end{array}$ & $\begin{array}{c}\mathbf{3}^{\text {rd }} \\
\text { experimental }\end{array}$ \\
\hline $\begin{array}{c}\text { Daily milk yield of natural } \\
\text { fat content, kg }\end{array}$ & $27.3 \pm 0.48$ & $28.4 \pm 0.48$ & $28.9 \pm 0.77$ & $28.1 \pm 0.58$ \\
\hline $\begin{array}{c}\text { Daily milk yield of 4 \% fat, } \\
\mathrm{kg}\end{array}$ & $28.2 \pm 0.48$ & $29.8 \pm 0.61$ & $29.7 \pm 0.79$ & $29.1 \pm 0.40$ \\
\hline $\begin{array}{c}\text { Gross milk yield of natural } \\
\text { fat content, kg }\end{array}$ & $8362.9 \pm 146.45$ & $8703.0 \pm 146.5$ & $8838.7 \pm 235.6$ & $8252.0 \pm 315.7$ \\
\hline $\begin{array}{c}\text { Gross milk yield of 4 \% fat, } \\
\mathrm{kg}\end{array}$ & $8619.2 \pm 146.1$ & $8891.5 \pm 160.5$ & $9079.2 \pm 244.4$ & $8365.9 \pm 312.1$ \\
\hline $\begin{array}{c}\text { Mass fraction of milk } \\
\text { protein, \% }\end{array}$ & $3.36 \pm 0.02$ & $3.41 \pm 0.03$ & $3.52 \pm 0.01 *$ & $3.40 \pm 0.01$ \\
\hline $\begin{array}{c}\text { Milk protein yield, } \\
\mathrm{kg}\end{array}$ & $278.7 \pm 5.56$ & $294.8 \pm 5.62$ & $310.2 \pm 8.56$ & $279.7 \pm 11.35$ \\
\hline $\begin{array}{c}\text { Mass fraction of milk fat, } \\
\%\end{array}$ & $4.21 \pm 0.03$ & $4.21 \pm 0.02$ & $4.27 \pm 0.01 \mathrm{y}$ & $4.21 \pm 0.01$ \\
\hline Milk protein yield, kg & $351.6 \pm 6.04$ & $365.6 \pm 7.02$ & $375.7 \pm 10.45$ & $346.3 \pm 13.33$ \\
\hline
\end{tabular}

Note: * - the difference is significant with respect to the control group at $P>0.95$

It was found that the introduction of $30 \%$ of grain in feed contributed to the reduction of gross yield of natural and $4 \%$ fat and amounted to $8252.0 \mathrm{~kg}$ and $8365.9 \mathrm{~kg}$ of milk, respectively.

For the first 10 months of lactation deviation of the gross yield of milk of natural fat content in the experimental groups was compared with the control group: + of $340.1 \mathrm{~kg}(4.07 \%),+475.8 \mathrm{~kg}$ $(5.69 \%),-110.86 \mathrm{~kg}(-1.33 \%)$, respectively.

The introduction of white lupine grain into the compound feed for dairy cows in the experimental groups had a minor impact on the content of the mass fraction of milk fat and was on the same level with the control group.

The data of experience show that in dairy cows of the 3rd experimental group, in which $24 \%$ of white lupine grain was introduced into the feed, the mass fraction of milk fat increased to $4.27 \%$ in the daily milk yield, which was higher by $0.06 \%$ compared with the animals of the control group.

The intake of nitrogen into the body of cattle depends on its content in the diet. A significant role in the nitrogen balance belongs to the quality of raw protein, the degree of its cleavage, amino acid content, as well as the method of preparing feed for use. A decrease in one or more parameters leads to the increase in nitrogen losses with feces and urine $[4 ; 7 ; 8]$.

The use of nitrogen by animals depends on the quality of fodder, the physiological state and the level of productivity of the animal. Nitrogen metabolism is a set of plastic processes of protein-, amino acids- and other nitrogen-containing substances transformations. Synthesis of microbial protein comes from ammonia, peptides and amino acids formed during the life of microorganisms $[1-4 ; 7]$.

Analyzing the data of the average daily nitrogen balance, it should be noted that it was positive in the experimental animals (Table 3). With the dairy cows of the 4th experimental group, in the compound feed, which included $30 \%$ of white lupine grain, there is an increase in nitrogen intake with a diet of $2.5 \%$ in relation to the control group, which is probably due to the high consumption of feed diet.

It is established that the flow of nitrogen in the diet was the greatest in the 4th experimental group. The least of its excretion from the body with feces was noted in the animals of the 2nd experimental group. 
However, nitrogen digestibility in the cows of the 2nd experimental group, which received $24 \%$ of white lupine grain as part of feed, was higher in relation to the control group. At the same time, nitrogen digestibility in group 4 was the lowest in relation to the control and the 2nd, 3rd experimental groups, and amounted to $70.9 \%$.

Table 3

Average daily nitrogen balance in dairy cows, $g$

\begin{tabular}{|c|c|c|c|c|}
\hline \multirow{2}{*}{ Indicator } & \multicolumn{4}{|c|}{ Group of animals $(n=3)$} \\
\hline & Control & $1^{\text {st }}$ experimental & $2^{\text {nd }}$ experimental & $3^{\text {rd }}$ experimental \\
\hline $\begin{array}{c}\text { Made of nitrogen } \\
\text { with a diet }\end{array}$ & $460.1 \pm 4.57$ & $460.4 \pm 2.05$ & $467.5 \pm 4.11$ & $471.4 \pm 3.56^{*}$ \\
\hline $\begin{array}{l}\text { Excreted nitrogen } \\
\text { with feces }\end{array}$ & $129.3 \pm 8.78$ & $120.9 \pm 2.70$ & $123.7 \pm 3.90$ & $136.8 \pm 7.46$ \\
\hline Digested nitrogen & $330.2 \pm 9.49$ & $339.5 \pm 4.10$ & $343.7 \pm 3.41$ & $334.1 \pm 10.99$ \\
\hline $\begin{array}{l}\text { Excreted nitrogen } \\
\text { in urine }\end{array}$ & $194.8 \pm 17.65$ & $205.2 \pm 6.52$ & $199.4 \pm 1.74$ & $206.9 \pm 6.56$ \\
\hline \multicolumn{5}{|c|}{ Nitrogen excreted: } \\
\hline with milk & $129.1 \pm 10.59$ & $130.3 \pm 3.18$ & $142.6 \pm 2.37 *$ & $124.7 \pm 5.76$ \\
\hline \multicolumn{5}{|c|}{ Nitrogen with milk excreted: } \\
\hline$\%$ of accepted & $28.1 \pm 2.44$ & $28.3 \pm 0.81$ & $30.5 \pm 0.31$ & $26.5 \pm 1.04$ \\
\hline$\%$ of digested & $39.0 \pm 4.33$ & $38.4 \pm 1.22$ & $41.5 \pm 0.38$ & $37.3 \pm 0.80$ \\
\hline \multicolumn{5}{|c|}{ Nitrogen assimilated: } \\
\hline$\%$ of accepted & $29.2 \pm 1.86$ & $29.2 \pm 0.78$ & $30.9 \pm 0.29$ & $27.0 \pm 0.75$ \\
\hline$\%$ of digested & $40.5 \pm 3.65$ & $39.5 \pm 1.26$ & $42.0 \pm 0.32$ & $38.1 \pm 0$ \\
\hline
\end{tabular}

Note: $*$ - the difference is significant with respect to the 2 nd experimental group at $P>0.95$

The highest digestibility of nitrogen was noted in the cows of the 3rd experimental group, receiving $24 \%$ of grain of white lupine Degas as part of feed.

The animals of the 1st, 2nd and 4th experimental groups had few differences in milk production. However, it should be noted that the content of $30 \%$ of lupine grain in the feed contributed to the decrease in the milk production of cows by $2.8 \%$.

An important indicator of use of nutrients under consumed diet is digestibility. The increase in this indicator leads to an improvement of the use efficiency of diet feed means $[1 ; 7 ; 10]$.

Analyzing the data of physiological experience, it was noted that the digestibility of all nutrients in the variants of the proposed concentrate feed was higher in relation to the 1 st control group.

Table 4

Digestibility of nutrients in experimental cows

\begin{tabular}{|l|c|c|c|c|}
\hline \multirow{2}{*}{ Indicator } & \multicolumn{4}{|c|}{ Group of animals $(\mathbf{n}=3)$} \\
\cline { 2 - 5 } & Control & $\mathbf{1}^{\text {st }}$ experimental & $\mathbf{2}^{\text {nd }}$ experimental & $\mathbf{3}^{\text {rd }}$ experimental \\
\hline Dry matter & $69.9 \pm 0.82$ & $70.6 \pm 0.27$ & $70.9 \pm 0.16$ & $68.3 \pm 0.66$ \\
\hline Organic matter & $70.89 \pm 0.91$ & $71.8 \pm 0.69$ & $71.6 \pm 0.65$ & $68.7 \pm 0.69$ \\
\hline Crude protein & $71.8 \pm 1.26$ & $72.2 \pm 0.98$ & $73.5 \pm 0.29$ & $70.9 \pm 0.25$ \\
\hline Crude fat & $50.7 \pm 1.48$ & $50.5 \pm 1.46$ & $50.8 \pm 0.45$ & $49.0 \pm 1.32$ \\
\hline Crude fiber & $57.9 \pm 1.21$ & $57.8 \pm 1.27$ & $57.9 \pm 1.47$ & $56.9 \pm 1.33$ \\
\hline $\begin{array}{l}\text { Nitrogen-free } \\
\text { extractive } \\
\text { substances }\end{array}$ & $77.4 \pm 1.06$ & $78.6 \pm 0.63$ & $78.2 \pm 0.34$ & $77.6 \pm 1.15$ \\
\hline
\end{tabular}

Analyzing the data of physiological experience, it should be noted that the digestibility of all diet nutrients with the compound feed containing 18 and $24 \%$ of lupine grain was higher in relation to the 4th experimental group, which was receiving the maximum share of lupine grain $-30 \%$ and the control groups (Table 4). 


\section{Conclusions}

1. The introduction of white lupine concentrate into the compound feed did not have a negative impact on the milk productivity, digestibility and nitrogen balance in cows. The increase in the daily milk yield of natural fat content by $5.86 \%$ and the mass fraction of protein by $0.16 \%$ was shown.

2. All animals had a positive nitrogen balance. The greatest nitrogen assimilation was in cows receiving $24 \%$ of white lupine grain in feed, both from accepted and from digested and amounted to 30.5 and $41.5 \%$, respectively.

3. The inclusion of $18 \%$ and $24 \%$ of lupine grain in the feed increased the digestibility of nutrients in the diet; however, $30 \%$ of the grain in the feed leads to a decrease in the digestibility of nutrients in relation to the control. To increase milk production and nitrogen absorption of the diet is recommended to use grain of white lupine in an amount of $24 \%$ of the concentrated portion of the diet.

\section{References}

[1] Lyle M. Role maintaining a healthy rumen: review. Advances in Dairy Technology (2000), vol. 12, pp. 101-108.

[2] Lypsylehmän ruokinta Painos: 1. Pianos. Juho Kyntäjä; Sanna Nokka Taina Harmoinen (toim.) Pro Agria Keskusten Liitto, 2010. 140 p.

[3] Overton T.R., Waldron M.R. Nutritional management of transition dairy cows. Strategies to optimize metabolic health. J. Dairy sci, 2004, No 87 (E. Suppl.), pp. 103-119.

[4] Ruminant physiology: digestion, metabolism, growth and reproduction / edited by P. Cronje; assoc. editors, E.A. Boomker, P.H. Henning, W. Schultheiss, J.G. van der Walt. CAB International. - 2000. 474 p.

[5] Castillo-González A.R., Burrola-Barraza M.E., Domínguez-Viveros J., Chávez-Martínez A. 2014. Rumen microorganisms and fermentation. Arch Med Vet, No 46, pp. 349-361.

[6] Brock F.M., Forsberg C.W., Buchanan-Smith J.G. 1982. Proteolytic activity of rumen microorganisms and effects of proteinase inhibitors. Appl Environ Microbiol, No 44, pp. 561-569.

[7] Claudia Barchiesi-Ferrari, René Anrique Ruminal degradation of dry matter and crude protein from moist dehulled lipin and extracted rapeseed meal. Chilean Journal of agricultural research, 2011, No 71(3), pp. 430-436.

[8] Yilkal Tadele. White Lupin (Lupinus albus) grain, a potential sourse of protein for ruminants: A review. Research Journal of Agriculture and Environmental Management, vol. 4 (4), pp. 180-188, April, 2015.

[9] Firkins J.L., Yu Z., Morrison M. 2007. Ruminal Nitrogen Metabolism: Perspectives for Integration of Microbiology and Nutrition for Dairy. J Dairy Sci, No 90, pp. 1-16.

[10] Masussi F., Francia A. Di., Romano R. etc. Effect of Lupinus albus as protein supplement on yield, constituents, clotting properties and fatty acid composition in ewes, milk. Small Ruminant Research 65 (2006), pp. 251-259.

[11] Sizova Yu.V. Influence of protein supplements on milk production of cows. Bulletin of NGIEI, 2013, No 12(31), pp. 83-87. 